\title{
球状 $\mathrm{Al}_{2} \mathrm{O}_{3}$ 粒子を分散した水酸アパタイトセラミックス
}

\author{
野間竜男・庄司典幸・和田智志・鈴木健之 \\ 東京農工大学工学部物質生物工学科, 184 東京都小金井市中町 2-24-16
}

\author{
Preparation of Spherical $\mathrm{Al}_{2} \mathrm{O}_{3}$ Particle Dispersed Hydroxyapatite Ceramics \\ Tatsuo NOMA, Noriyuki SHOJI, Satoshi WADA and Takeyuki SUZUKI \\ Department of Applied Chemistry, Tokyo University of Agriculture and Technology, 2-24-16, Nakamachi, Koganei-shi, Tokyo
}

184

[Received March 24, 1993; Accepted May 21, 1993]

\begin{abstract}
Hydroxyapatite (HAp) powders with spherical $\mathrm{Al}_{2} \mathrm{O}_{3}$ particles dispersion were synthesized by a wet process or hydrothermal process. The transmission electron microscopic observations of $\mathrm{Al}_{2} \mathrm{O}_{3}-\mathrm{HAp}$ powder mixtures showed that the $\mathrm{Al}_{2} \mathrm{O}_{3}$ particles were uniformly dispersed in and surrounded by fine HAp crystals. $\mathrm{Al}_{2} \mathrm{O}_{3}$-HAp composite ceramics were prepared by hot pressing at $1000^{\circ} \mathrm{C}$ under $50 \mathrm{MPa}$ for $1 \mathrm{~h}$. The fracture toughness of the ceramics with $\mathrm{Al}_{2} \mathrm{O}_{3}$ dispersion increased up to 1.80 times that of pure HAp ceramics.
\end{abstract}

Key-words : Hydroxyapatite, $\mathrm{Al}_{2} \mathrm{O}_{3}$, Sphere, Composite, Fracture toughness, Hydrothermal

\section{1. 緒 言}

水酸アパタイト（以下HAp と略記）は生体の硬組織を 構成する主成分であり，組織適合性に優れ，骨や歯と直接 強固に結合するという性質に着目して一部実用化されてい る。しかしながら, HAp 焼結体は典型的な低勒性セラミッ クスであり，透光性を示すまで十分に緻密化した焼結体で あっても破壊勒性 $K_{\mathrm{IC}}$ は約 $1.1 \mathrm{MPa} \cdot \mathrm{m}^{1 / 2}$ にすぎず1)， HAp 焼結体を負荷のかかる部位に単独で用いることは困 難であり，応用範囲が限定されている．したがって，機械 的特性，特に破壊勒性を向上させることが HAp セラミッ クスを幅広く利用するための必要な条件である.

一般に他成分との複合化はセラミックスの機械的性質の 向上に有効であることが知られており2)，これまでも， HAp の複合化については，いくつかの報告例がある3) 5). 著者らはこれまでに HAp と $\mathrm{SiC}$ 板状粒子との複合化を試 み(6),7)，硬さ及び破壊勒性の向上を報告してきた。しかし ながら， $\mathrm{SiC} と \mathrm{HAp}$ マトリックスの熱膨張係数の大きな 違いにより $\mathrm{SiC}$ の周囲には亀裂が生じてしまい，強度は 向上しなかった。本研究の目的は熱膨張係数がマトリック スである $\mathrm{HAp}$ のそれと比較的近い $\mathrm{Al}_{2} \mathrm{O}_{3}$ 粒子を分散さ せ、破壊勒性の向上した複合せラミックスを作製すること である。更に分散する $\mathrm{Al}_{2} \mathrm{O}_{3}$ 粒子には形状及び粒度を厳 密に制御した球状粒子を用い，セラミックスの機械的性質 の向上を図った.

\section{2. 実験方法}

分散 $\mathrm{Al}_{2} \mathrm{O}_{3}$ 粒子として, アルミニウムイソプロポキシ
ド $\left(\mathrm{Al}\left(\mathrm{OCH}\left(\mathrm{CH}_{3}\right)_{2}\right)_{3}\right)$ (キシダ化学製, 試薬 1 級 $)$ を原料 にミスト熱分解法により合成後, 更に $1200^{\circ} \mathrm{C}$ で 4 時間熱 処理した球状 $\mathrm{Al}_{2} \mathrm{O}_{3}$ 粒子を用いた. 比較のため, 市販 $\mathrm{Al}_{2} \mathrm{O}_{3}$ 試薬（和光純薬工業製, 試薬特級) を $1500^{\circ} \mathrm{C}$ で 4 時間仮 焼し，これを粉砕・沈降分級して調製した $\mathrm{Al}_{2} \mathrm{O}_{3}$ 粒子女 使用した。

$\mathrm{NH}_{3}$ 水により $\mathrm{pH} 10$ に調整した0.167 M の Ca $\left(\mathrm{NO}_{3}\right)_{2}$. $4 \mathrm{H}_{2} \mathrm{O}$ (国産化学製, 試薬特級) 水溶液に, $\mathrm{Al}_{2} \mathrm{O}_{3}$ 粒子を $\mathrm{Al}_{2} \mathrm{O}_{3}$ - $\mathrm{HAp}$ 系に対して 5 20 vol\% となるように添加し, これに同じく $\mathrm{NH}_{3}$ 水により $\mathrm{pH} 10$ に調整した $0.1 \mathrm{M}$ の $\left(\mathrm{NH}_{4}\right)_{2} \mathrm{HPO}_{4}$ （国産化学製, 試薬特級) 水溶液を室温で 滴下し，ゲル状の沈殿を得た。このゲルを湿式及び水熱の 二つの方法で $\mathrm{Al}_{2} \mathrm{O}_{3}$ 粒子の周りに $\mathrm{HAp}$ 微粒子を結晶化さ せた。すなわち, 沈殿をかくはんしながら，常圧下， $96^{\circ} \mathrm{C}$ で 24 時間の湿式処理（湿式法）, 又はかくはんしなが ら， $150^{\circ} \mathrm{C}, 0.5 \mathrm{MPa}$ で 4 時間の水熱処理（水熱法）によ り $\mathrm{Al}_{2} \mathrm{O}_{3}-\mathrm{HAp}$ 系複合粉体を得た。それぞれの複合粉体を 吸引洰過し, 水洗後, 大気中約 $70^{\circ} \mathrm{C}$ で完全に乾燥し, 更 に電気炉で $600^{\circ} \mathrm{C} て ゙ 1$ 時間仮焼し, $\mathrm{Al}_{2} \mathrm{O}_{3}$ 乳鉢中で乾式粉

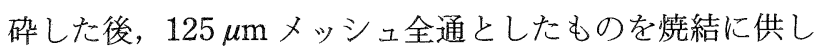
た。これをべークライト型で手押し成形し，ゴム袋に入れ 脱気した後, $150 \mathrm{MPa}$ で 1 分間の等方圧加圧成形 (CIP) を行った。 CIP 成形後のペレットを $\mathrm{Al}_{2} \mathrm{O}_{3}$ 製の型に入れ $1000^{\circ} \mathrm{C}, 50 \mathrm{MPa}$ で 1 時間の加圧焼結 ( $\mathrm{HP}$ ) を行った.

得られた $\mathrm{Al}_{2} \mathrm{O}_{3}-\mathrm{HAp}$ 系複合体の粒子の形状及び混合状 態を透過型電子顕微鏡（TEM; 日立 $\mathrm{H}-700 \mathrm{H}, 200 \mathrm{kV}$ ) で観察した。焼結体のかさ密度は水銀を用いたアルキメデ ス法により測定し，相対密度は $\alpha-\mathrm{Al}_{2} \mathrm{O}_{3}$ と $\mathrm{HAp}$ の理論密 度 $\left(\alpha-\mathrm{Al}_{2} \mathrm{O}_{3}: 3.97 \mathrm{~g} / \mathrm{cm}^{3}, \mathrm{HAp}: 3.16 \mathrm{~g} / \mathrm{cm}^{3}\right)$ 及びそれぞれ の体積分率とから算出した值に対して求めた. 結晶相の同 定には粉末 $\mathrm{X}$ 線回折装置 (XRD; 理学電機製, Geigerflex RAD-2B, $30 \mathrm{kV}, 20 \mathrm{~mA}, \mathrm{Cu} \mathrm{K} \alpha$ 線）を使用した. ダ イヤモンド研磨装置（マルトー製，ML-150）を用い 4 $\mu \mathrm{m}$ のダイアモンドペーストで焼結体を鏡面研磨した。 た, 焼結体中の $\mathrm{Al}_{2} \mathrm{O}_{3}$ 粒子の分散状態, 破壊形態等の微 構造を走査型電子顕微鏡 (SEM; JEOL 製, JSM-T100, $25 \mathrm{kV})$ で観察した。焼結体の機械的特性の評価はビッ カ一ス硬さ $\left(H_{\mathrm{v}}\right)$ 及び破壊勒性 $\left(K_{\mathrm{IC}}\right)$ を測定して行った. ビッカース硬さは微小硬さ計（明石製作所製：MVK-E） 
で荷重300 gf で15秒間の条件で測定した。 $K_{\mathrm{IC}}$ の測定は, ビッカース压の周りに生ずる亀裂の長さから求める，微 小圧子押し込み法（IM 法）により，新原の式8)を用いて 求めた。

\section{3. 結果及び考察}

$\mathrm{XRD}$ によるとミスト熱分解法により合成した $\mathrm{Al}_{2} \mathrm{O}_{3}$ 粒 子は非晶質であったが，これを $1200^{\circ} \mathrm{C} て ゙ ~ 4$ 時間熱処理す ることにより $\alpha-\mathrm{Al}_{2} \mathrm{O}_{3}$ 単相となった。ミス卜熱分解により 得られた $\mathrm{Al}_{2} \mathrm{O}_{3}$ 粒子は真球状の緻密な非凝集粒子であっ たが，熱処理によってもその形状等にほとんど変化は見ら れなかった．図１は熱処理・結晶化させた，ミス卜熱分解 法による球状 $\mathrm{Al}_{2} \mathrm{O}_{3}$ 粒子（以降 $M-\mathrm{Al}_{2} \mathrm{O}_{3}$ ), 及び仮焼・沈 降分級により得られた $\mathrm{Al}_{2} \mathrm{O}_{3}$ 粒子（以降 $A-\mathrm{Al}_{2} \mathrm{O}_{3}$ ）の $\mathrm{SEM}$ 写真である。 $M-\mathrm{Al}_{2} \mathrm{O}_{3}$ を結晶化させた理由は，分散 させる第 2 相粒子が非晶質である場合，マトリックスで める HApのCa が取り込まれる恐れがあることと6)，ま た $A-\mathrm{Al}_{2} \mathrm{O}_{3}$ 粒子の分散と比較するためである。なお， $M-$ $\mathrm{Al}_{2} \mathrm{O}_{3}$ の平均粒子径は $0.44 \mu \mathrm{m}$ であり粒度分布かかなり狭 い粒子となっていた。一方, $A-\mathrm{Al}_{2} \mathrm{O}_{3}$ の粒度分布は $M$ $\mathrm{Al}_{2} \mathrm{O}_{3}$ に比較して広く, 平均粒子径は $1.98 \mu \mathrm{m}$ であった。

XRD より， $M-\mathrm{Al}_{2} \mathrm{O}_{3}-\mathrm{HAp}$ 系， $A-\mathrm{Al}_{2} \mathrm{O}_{3}-\mathrm{HAp}$ 系複合粉 体からはそれぞれ $\mathrm{HAp} と \alpha-\mathrm{Al}_{2} \mathrm{O}_{3}$ のピークのみが見ら れ，そのほかの相は認められなかった。図 2 に $M-\mathrm{Al}_{2} \mathrm{O}_{3}-$ $\mathrm{HAp}$ 系, 及び $A-\mathrm{Al}_{2} \mathrm{O}_{3}-\mathrm{HAp}$ 系複合粉体の TEM 写真を 示す. 分散した $M-\mathrm{Al}_{2} \mathrm{O}_{3}, A-\mathrm{Al}_{2} \mathrm{O}_{3}$ は湿式，水熱処理にか かわらず $\mathrm{HAp}$ 微結晶で取り团なれて抢り， $\mathrm{Al}_{2} \mathrm{O}_{3}$ 粒子同 士の直接接触はほとんど見られなかった。

図 3 に $M-\mathrm{Al}_{2} \mathrm{O}_{3}$ 及び $A-\mathrm{Al}_{2} \mathrm{O}_{3}$ の添加率に対する焼結体 の相対密度を示す。 $\mathrm{Al}_{2} \mathrm{O}_{3}$ の焼結温度は $\mathrm{HAp}$ より高い
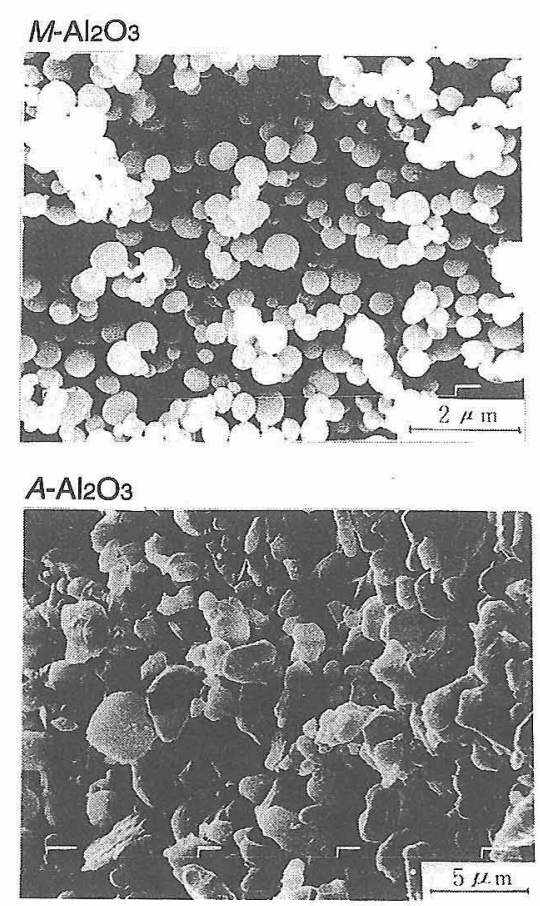

Fig. 1. SEM photographs of $M-\mathrm{Al}_{2} \mathrm{O}_{3}$ and $A-\mathrm{Al}_{2} \mathrm{O}_{3}$.

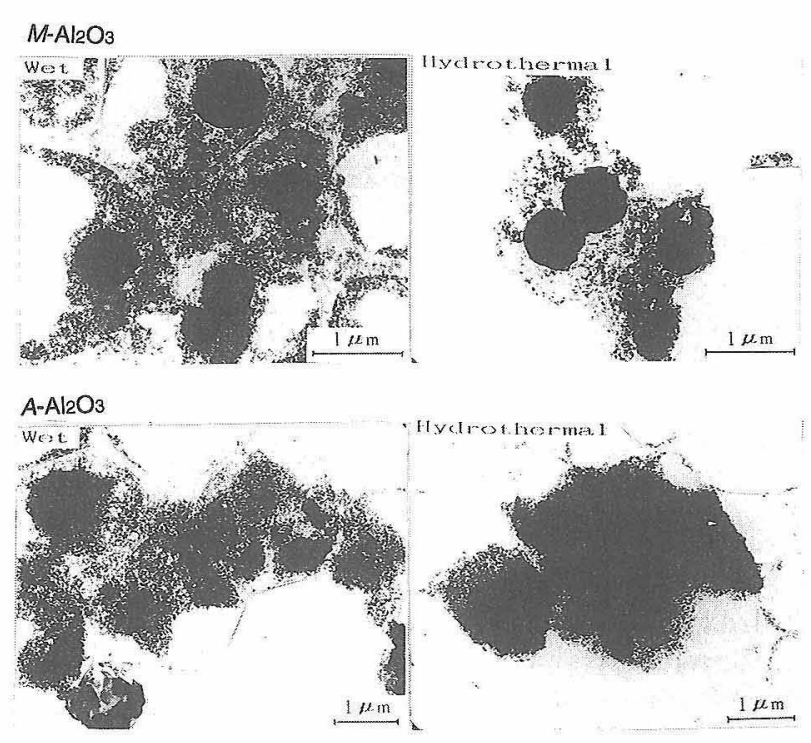

Fig. 2. TEM photographs of $M-\mathrm{Al}_{2} \mathrm{O}_{3}-\mathrm{HAp}$ and $A-\mathrm{Al}_{2} \mathrm{O}_{3}-\mathrm{HAp}$ composite powders.

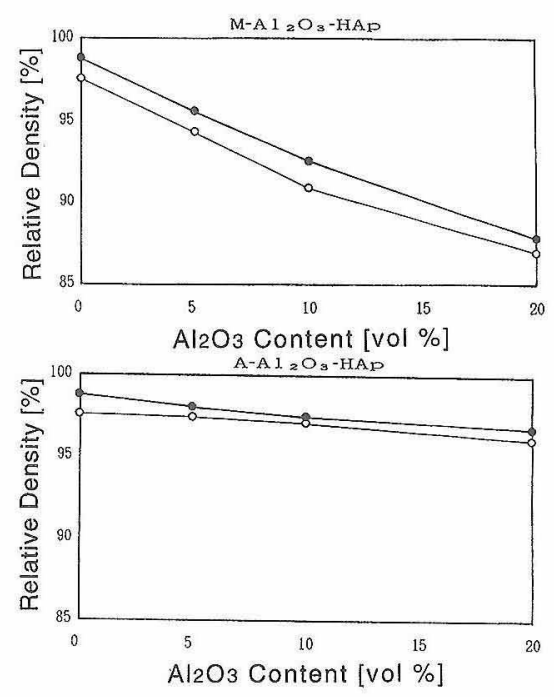

Fig. 3. Relative densities of $\mathrm{Al}_{2} \mathrm{O}_{3}-\mathrm{HAp}$ composite ceramics as a function of $\mathrm{Al}_{2} \mathrm{O}_{3}$ content. Open circles and closed circles represent wet process and hydrothermal process, respectively.

ため， $\mathrm{HAp} の$ 粒子間隔の減少を妨げ， $\mathrm{Al}_{2} \mathrm{O}_{3}$ 添加率の増 加に従って相対密度は減少した。 また, 湿式試料と水熱試 料を比較してみると，水熱合成粉体からの暁結体の方が高 い密度を示し，水熱合成粉体からの HAp 単体では透光性 を示すまでに至った。一般に純粋な HAp は約 $1300^{\circ} \mathrm{C}$ 以上 の加熱で次式のようにリン酸三カルシウム (TCP) と $\mathrm{CaO}$ あるいはリン酸四カルシウムとに分解することが知 られている゙

$$
\begin{aligned}
& \mathrm{Ca}_{10}\left(\mathrm{PO}_{4}\right)_{6}(\mathrm{OH})_{2} \rightarrow 3 \mathrm{Ca}_{3}\left(\mathrm{PO}_{4}\right)_{2}+\mathrm{CaO}+\mathrm{H}_{2} \mathrm{O} \uparrow \text { 又は } \\
& \mathrm{Ca}_{10}\left(\mathrm{PO}_{4}\right)_{6}(\mathrm{OH})_{2} \rightarrow 2 \mathrm{Ca}_{3}\left(\mathrm{PO}_{4}\right)_{2}+\mathrm{Ca}_{4}\left(\mathrm{PO}_{4}\right)_{2} \mathrm{O} \\
& +\mathrm{H}_{2} \mathrm{O} \uparrow
\end{aligned}
$$

湿式合成粉体からの焼結体の場合，HAp 単体に括いても 本研究の焼結温度 $\left(1000^{\circ} \mathrm{C}\right)$ で $\alpha$-TCP への分解が見られ た.しかしながら，これは湿式合成 HAp の組成の不均質 

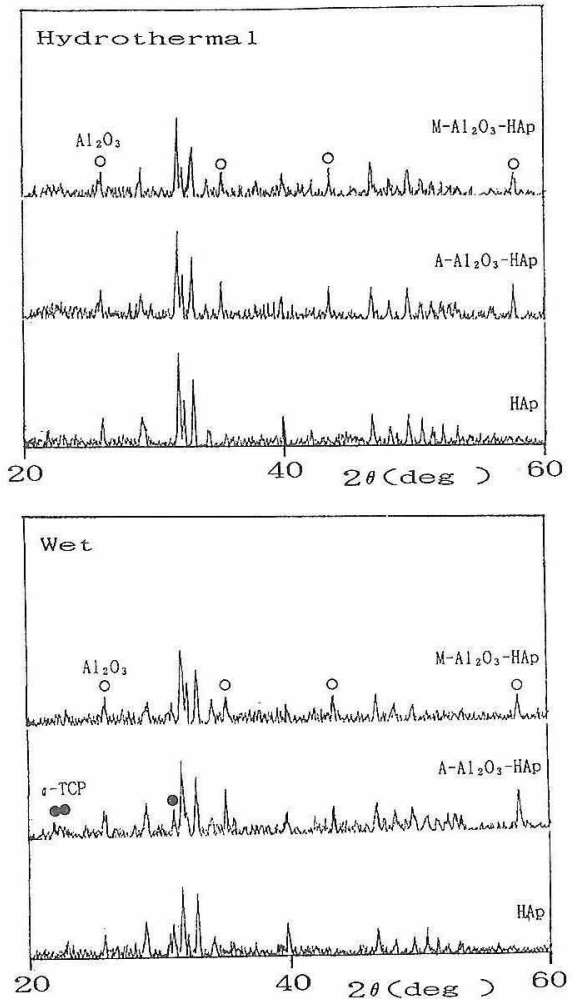

Fig. 4. $\mathrm{XRD}$ profiles of $\mathrm{Al}_{2} \mathrm{O}_{3}-\mathrm{HAp}$ composite ceramics with 20 vol\% $\mathrm{Al}_{2} \mathrm{O}_{3}$ content.

性がもたらす真性的な性質であり，水熱合成粉体からの焼 結体では $\mathrm{Al}_{2} \mathrm{O}_{3}$ を20 vol\%添加したものでも HAp と $\alpha$ $\mathrm{Al}_{2} \mathrm{O}_{3}$ 以外の結晶相は検出されなかった（図 4).このこ とは $\mathrm{Al}_{2} \mathrm{O}_{3}$ の添加が $\mathrm{HAp}$ の化学組成に影響を及ぼさず， 同時に分散させる $\mathrm{Al}_{2} \mathrm{O}_{3}$ の種類によらないことを示して いる。なた，湿式試料からの焼結体の方が密度が低くなっ ているのは TCP への分解に伴う $\mathrm{H}_{2} \mathrm{O}$ 蒸発によって焼結 体の緻密化が阻害されたためであると考えられる。M$\mathrm{Al}_{2} \mathrm{O}_{3}$ 系， $A-\mathrm{Al}_{2} \mathrm{O}_{3}$ 系の両者を比較してみると添加率20 $\mathrm{vol} \%$ の相対密度は， $M-\mathrm{Al}_{2} \mathrm{O}_{3}$ 系では水熱試料で $87.9 \%$ ， 湿式試料で87.1\%であり， $A-\mathrm{Al}_{2} \mathrm{O}_{3}$ 系では水熱試料で $96.8 \%$ ，湿式試料で $96.2 \%$ となって拈り， $M-\mathrm{Al}_{2} \mathrm{O}_{3}$ を分散 させた複合焼結体の方が密度の低下が著しかった。

焼結体の破面の SEM 観察より， $M-\mathrm{Al}_{2} \mathrm{O}_{3}, A-\mathrm{Al}_{2} \mathrm{O}_{3}$ は マトリックス中にはほぼ均一に分散しており，また $M$ $\mathrm{Al}_{2} \mathrm{O}_{3}$ 粒子は $\mathrm{HP}$ 後も割れたり歪んだりすることなく球形 を保っていた。しかしながら， $M-\mathrm{Al}_{2} \mathrm{O}_{3}-\mathrm{HAp}$ 系複合焼結 体中においては $M \cdot \mathrm{Al}_{2} \mathrm{O}_{3}$ 同士の凝集が部分的に観察され た（図 5). 圧粉体の破断面の SEM 観察上り，焼結以前 にこの部分的な凝集が生じていることが分かった。ミミスト 熱分解合成時は非凝集性の単分散粒子が得られているが， 結晶化のため $1200^{\circ} \mathrm{C} て ゙ 4$ 時間の熱処理時に凝集が生じる ことが確認された。焼結体の破面のSEM 観察より $M$ $\mathrm{Al}_{2} \mathrm{O}_{3}-\mathrm{HAp}$ 系, $A-\mathrm{Al}_{2} \mathrm{O}_{3}-\mathrm{HAp}$ 系複合焼結体共に $\mathrm{Al}_{2} \mathrm{O}_{3}$ 粒子の抜けた穴はよく見られたが， $\mathrm{Al}_{2} \mathrm{O}_{3}$ の添加量が大き くなっても HAp マトリックス中には気孔がほとんど見ら 机なかった。したがって, 先に示した $M-\mathrm{Al}_{2} \mathrm{O}_{3}-\mathrm{HAp}$ 系複

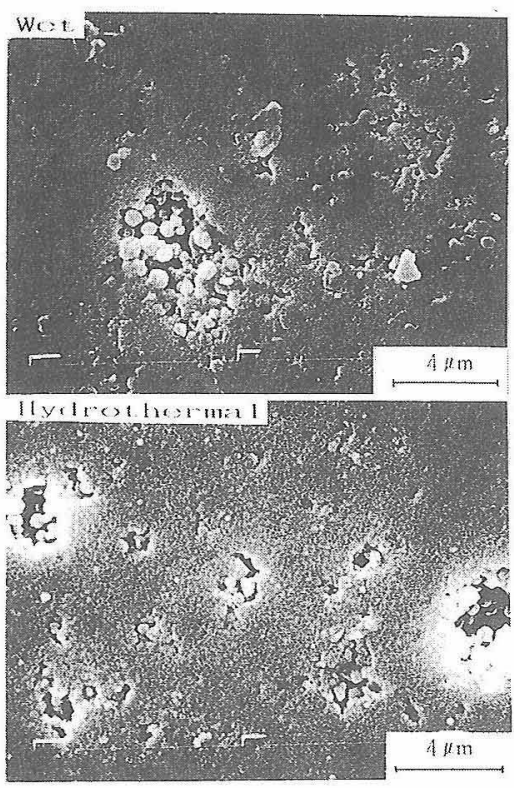

Fig. 5. SEM photographs of $M-\mathrm{Al}_{2} \mathrm{O}_{3}-\mathrm{HAp}$ composite ceramics with 20 vol\% $\mathrm{Al}_{2} \mathrm{O}_{3}$ content.

合体の $\mathrm{Al}_{2} \mathrm{O}_{3}$ 添加による相対密度の大きな減少は, $\mathrm{Al}_{2} \mathrm{O}_{3}$ 粒子同士の凝集によるものである。すなわち， $\mathrm{Al}_{2} \mathrm{O}_{3}$ 粒子 は本実験での焼結温度 $\left(1000^{\circ} \mathrm{C}\right)$ では焼結しないので, 凝集粒子を形成している $\mathrm{Al}_{2} \mathrm{O}_{3}$ 粒子間には大きな空隙を 残し，更にこの $\mathrm{Al}_{2} \mathrm{O}_{3}$ 粒子の凝集は $\mathrm{Al}_{2} \mathrm{O}_{3}$ の添加量が增 加するにつれて多くなるので $M-\mathrm{Al}_{2} \mathrm{O}_{3}-\mathrm{HAp}$ 系では $\mathrm{Al}_{2} \mathrm{O}_{3}$ の添加量が増加するにつれて，焼結体の相対密度は減少す ることになる。一方， $A-\mathrm{Al}_{2} \mathrm{O}_{3}-\mathrm{HAp}$ 系複合焼結体では， $\mathrm{Al}_{2} \mathrm{O}_{3}$ 粒子は焼結体中に凝集体をほとんど作ることなく均 一に分散しているので，マトリックスの緻密化を阻害する のは $\mathrm{Al}_{2} \mathrm{O}_{3}$ 粒子表面近傍だけとなり， $\mathrm{Al}_{2} \mathrm{O}_{3}$ の添加によっ て若干密度は低下するものの, その程度はわずかである。 $M-\mathrm{Al}_{2} \mathrm{O}_{3}$ の熱処理時の凝集を抑制することが今後の課題 である。

図 6 に燒結体のビッカース硬さ $\left(H_{\mathrm{V}}\right)$ を $\mathrm{Al}_{2} \mathrm{O}_{3}$ 添加率 に対してプロットしたもの，図７に破壊勒性（ $K_{\text {IC }}$ ）を $\mathrm{Al}_{2} \mathrm{O}_{3}$ 添加率に対してプロットしたものを示す。ビッカー ス硬さについて見てみると，A- $\mathrm{Al}_{2} \mathrm{O}_{3}-\mathrm{HAp}$ 系複合体では $\mathrm{Al}_{2} \mathrm{O}_{3}$ の添加率の増加とともに硬さは上昇し， $\mathrm{Al}_{2} \mathrm{O}_{3} 20$ vol\%の添加で湿式試料では856 kgf $/ \mathrm{mm}^{2}$ ，水熱試料では $890 \mathrm{kgf} / \mathrm{mm}^{2}$ とそれぞれ HAp 単体の1.34倍, 1.30 倍の值 を示した。一方， $M-\mathrm{Al}_{2} \mathrm{O}_{3}-\mathrm{HAp}$ 系複合体では逆に $\mathrm{Al}_{2} \mathrm{O}_{3}$ の添加によって硬さは減少した．これらの相違については 以下のように考えられる。すなわち，通常，炾結体の硬さ はその密度に関連づけられる。 $A-\mathrm{Al}_{2} \mathrm{O}_{3}-\mathrm{HAp}$ 系では $\mathrm{Al}_{2} \mathrm{O}_{3}$ 添加率20 vol\%でもその密度は湿式・水熱共に $96 \%$ 以上で あり， $\mathrm{Al}_{2} \mathrm{O}_{3}$ の添加は複合体の密度にそれほぼ大きな影響 を与えてはいない。しかしながら， $M-\mathrm{Al}_{2} \mathrm{O}_{3}-\mathrm{HAp}$ 系では 複合体の密度に対する $\mathrm{Al}_{2} \mathrm{O}_{3}$ 添加の影響は著しく, $\mathrm{Al}_{2} \mathrm{O}_{3}$ 20 vo1\%の添加では湿式87.1\%，水熱87.9\%にまで相対密 度は低下し，A- $\mathrm{Al}_{2} \mathrm{O}_{3}-\mathrm{HAp}$ 系とは実に $10 \%$ 近い差が生じ ている。したがって，A- $\mathrm{Al}_{2} \mathrm{O}_{3}-\mathrm{HAp}$ 系では密度低下によ 


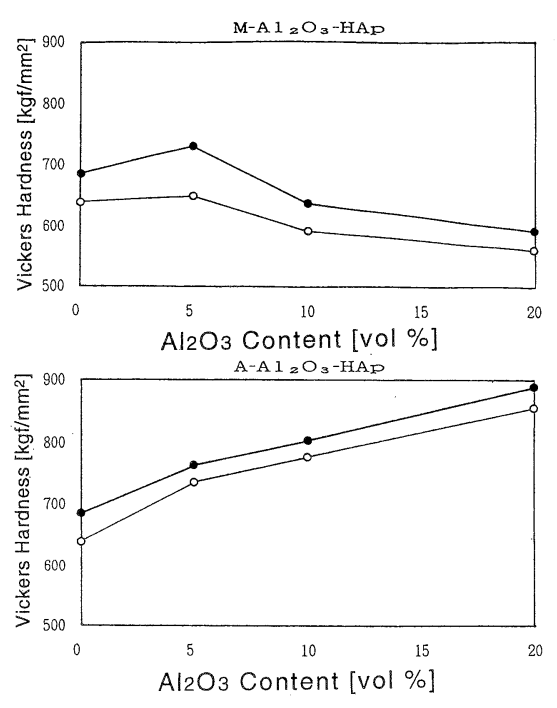

Fig. 6
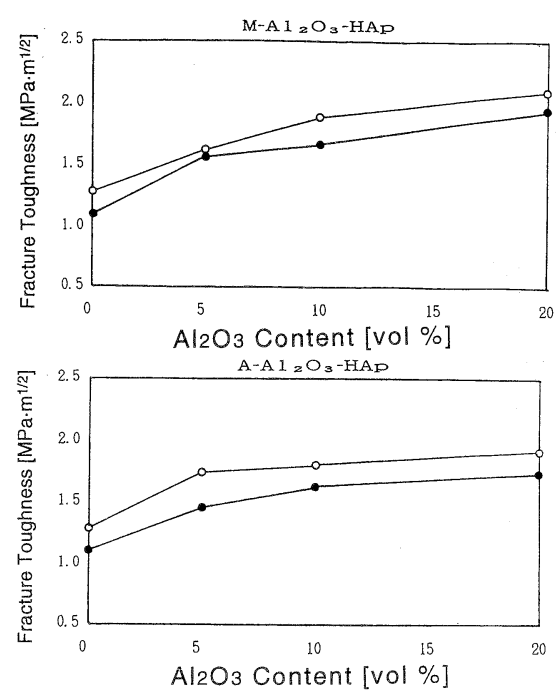

Fig. 7
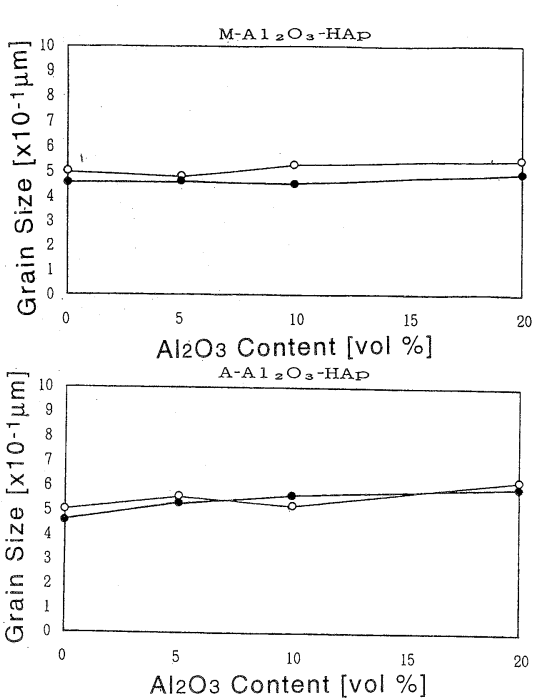

Fig. 8

Fig. 6. Micro Vickers hardness of $\mathrm{Al}_{2} \mathrm{O}_{3}-\mathrm{HAp}$ composite ceramics as a function of $\mathrm{Al}_{2} \mathrm{O}_{3}$ content. Open circles and closed circles represent wet process and hydrothermal process, respectively.

Fig. 7. Fracture toughness of $\mathrm{Al}_{2} \mathrm{O}_{3}-\mathrm{HAp}$ composite ceramics as a function of $\mathrm{Al}_{2} \mathrm{O}_{3}$ content. Open circles and closed circles represent wet process and hydrothermal process, respectively.

Fig. 8. Grain size of $\mathrm{Al}_{2} \mathrm{O}_{3}-\mathrm{HAp}$ composite ceramics as a function of content. Open circles and closed circles represent wet process and hydrothermal process, respectively.

る硬さの減少よりも, $\mathrm{Al}_{2} \mathrm{O}_{3}$ 添加による硬さ上昇への寄与 の方が上回っていたために， $\mathrm{Al}_{2} \mathrm{O}_{3}$ の添加とともに硬さは 上昇したが, 逆に $M-\mathrm{Al}_{2} \mathrm{O}_{3}-\mathrm{HAp}$ 系では密度低下による硬 さの減少の影響が大きかったために硬さは低下した． $M$ $\mathrm{Al}_{2} \mathrm{O}_{3}-\mathrm{HAp}$ 系の $\mathrm{Al}_{2} \mathrm{O}_{3} 5$ vol\%のところで硬さが一度増加 しているのは，ここでの相対密度が湿式 $94.5 \%$, 水熱 $96.7 \%$ と比較的大きく, 密度低下による硬さ減少への影響 が少なかったためである。

破壊勒性について見てみると $M-\mathrm{Al}_{2} \mathrm{O}_{3}-\mathrm{HAp}$ 系， $A$ $\mathrm{Al}_{2} \mathrm{O}_{3}-\mathrm{HAp}$ 系共に $\mathrm{Al}_{2} \mathrm{O}_{3}$ の添加量が増加するに従って破 壊勒性は大きくなっている。 また, 同じ条件であれば $A$ $\mathrm{Al}_{2} \mathrm{O}_{3}-\mathrm{HAp}$ 系よりも $M-\mathrm{Al}_{2} \mathrm{O}_{3}-\mathrm{HAp}$ 系の方が大きな值を 示している. 更に言えることは，同じ系の湿式及び水熱合 成粉からの複合体の破壊勒性を見た場合，湿式合成粉から の複合体の破壊勒性の方が，必ず大きくなっている。勒性 值向上のメカニズムについては後で考察するが，水熱より も湿式合成粉からの複合体の方が大きな破壊勒性を示す理 由としては次のように考元る。すなわち，破壞勒性（ $\left.K_{\mathrm{IC}}\right)$ はヤング率 $(E)$ とぜい性破壊開始に必要なエネルギー $\left(\gamma_{\mathrm{i}}\right)$ との間には次式の関係がある10).

$$
K_{\mathrm{IC}}=\left(2 \cdot E \cdot \gamma_{\mathrm{i}}\right)^{1 / 2}
$$

なお，

$$
\gamma_{\mathrm{i}}=\left(\gamma_{\mathrm{s}}+\gamma_{\mathrm{etc}}\right) \mu
$$

ここで $\gamma_{\mathrm{s}}$ は平坦な新表面を作るのに要する表面エネル ギー， $\gamma_{\mathrm{etc}}$ はそのほかのエネルギーである。

焼結体の気孔率が大きくなると普通，ヤング率並びに破 壞エネルギー $\gamma_{\mathrm{i}}$ が減少し，したがって破壊勒性が低下す る. しかし, 気孔によりクラックの枝分かれが生じ $\gamma_{\mathrm{s}}$ が 増加したり, ピン止めにより $\gamma_{\mathrm{etc}}$ が増加して, 逆に気孔に より破壊勒性が向上することになる。

一般に，IM 法によって得られた $K_{\mathrm{IC}}$ の絶対評価には注
意を要すると言われているが8),11)，その相対的な評価には

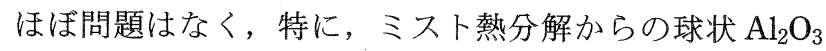
粒子を分散した $M-\mathrm{Al}_{2} \mathrm{O}_{3}-\mathrm{HAp}$ 系複合粉体においては, $\mathrm{Al}_{2} \mathrm{O}_{3}$ 添加率 $20 \mathrm{vol} \%$ で, $\mathrm{HAp}$ 単体に対して湿式で1.65 倍, 水熱で1.80倍の值を示し, $\mathrm{HAp}$ に対する $\mathrm{Al}_{2} \mathrm{O}_{3}$ の添 加は焼結体の破壊勒性の向上に有効であることが分かっ た。

図 8 KM- $\mathrm{Al}_{2} \mathrm{O}_{3}, A-\mathrm{Al}_{2} \mathrm{O}_{3}-\mathrm{HAp}$ 系複合体の $\mathrm{Al}_{2} \mathrm{O}_{3}$ の添 加量に対する HAp マトリックスの粒径の変化を示す. $\mathrm{Al}_{2} \mathrm{O}_{3}$ の添加の有無, 更にその添加量によっても粒径はほ とんど変化せず, $0.5 \mu \mathrm{m}$ 前後であった。 また, $M-\mathrm{Al}_{2} \mathrm{O}_{3}$, $A-\mathrm{Al}_{2} \mathrm{O}_{3}-\mathrm{HAp}$ 系を問わず，湿式合成粉体からの焼結体の 粒径は水熱合成粉体のそれよりも常に大きくなっていた。 緻密化は粒成長々同時に, 気孔が体積拡散ないし粒界拡散 により消失することによって起こるが，粒成長速度が速い と, 粒界の移動速度が気孔の移動速度よりも速くなり, 気 孔が粒内に取り残され気孔の消失は困難になる ${ }^{12)} . \mathrm{Al}_{2} \mathrm{O}_{3}-$ HAp 系複合体の密度において, 湿式合成粉体からの焼結 体の方が水熱合成粉体からのものより小さな密度を示して いるのは, マトリックスの粒成長速度の相対的な差にも起 因する可能性がある。一般に粒界が破壊の進展の障壁にな ると考えた場合, 粒径が小さい方が, 材料の持つ強度が大 きいことが知られている13). 破壊勒性は強度にも関連づ けられるが，破壞勒性に大きな差がない場合には粒径によ る強度の影響が大きくなるので, 水熱合成粉体を用いるこ とによって, より強度の高い焼結体が得られると予想され る.

図 9 に複合体の破面を示すが, 複合体の破壊形態は $M$ $\mathrm{Al}_{2} \mathrm{O}_{3}, A-\mathrm{Al}_{2} \mathrm{O}_{3}-\mathrm{HAp}$ 系共に粒界破壊が支配的であること が分かった．図10に燒結体の鏡面研磨面にビッカース圧子 を押し込むことにより発生した亀裂の進展の様子を示した. 


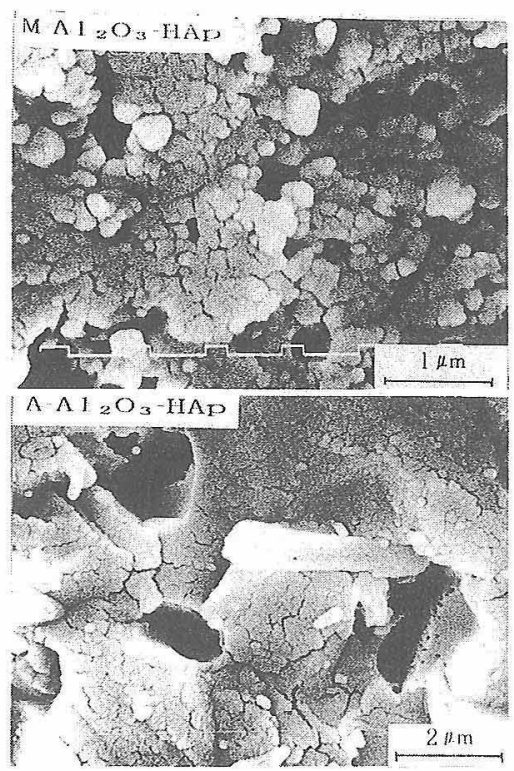

Fig. 9. SEM photographs of fracture surface of $\mathrm{Al}_{2} \mathrm{O}_{3}-\mathrm{HAp}$ composite ceramics with $20 \mathrm{vol} \% \mathrm{Al}_{2} \mathrm{O}_{3}$ content.

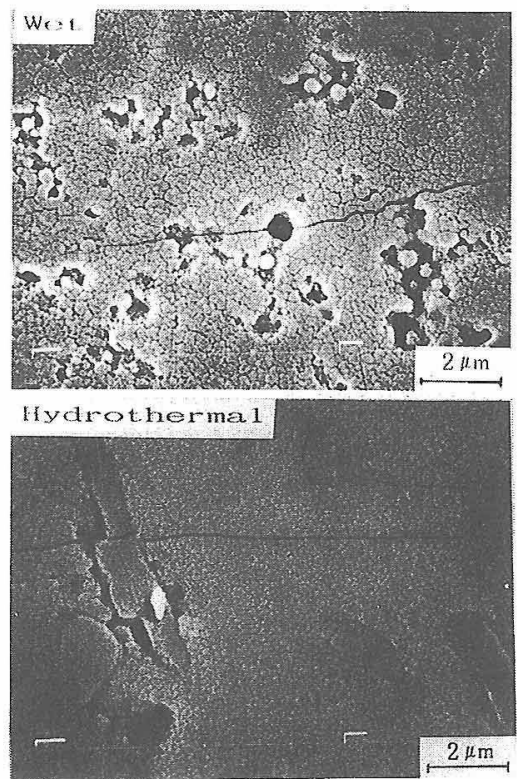

Fig. 10. SEM photographs of surface crack induced by a Vickers indentation on $\mathrm{Al}_{2} \mathrm{O}_{3}$ - HAp composite ceramics.

HAp 単体の焼結体では亀裂がほぼ直線的に進展していた のに対し， $M-\mathrm{Al}_{2} \mathrm{O}_{3}-\mathrm{HAp}$ 系複合体ではクラックが $\mathrm{HAp}-$

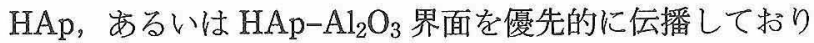
クラックの偏向が顕著であることが分かった。更に，A$\mathrm{Al}_{2} \mathrm{O}_{3}-\mathrm{HAp}$ 系複合体ではクラックは 2 相の界面のみなら ず，分散相を貫通して進展していることが見られた。した がって、これらの系の高勒化には少なくとむ,クラックの 湾曲 (bowing) と偏向 (deflection) の二つの機構が寄与 していることが分かった。

\section{4. 総 括}

$\mathrm{HAp}$ 微結晶の合成法を発展させ, $\mathrm{Al}_{2} \mathrm{O}_{3}-\mathrm{HAp}$ 系複合粉 体を湿式処理，及び水熱処理によって合成し，得られた複 合粉体を $1000^{\circ} \mathrm{C}, 50 \mathrm{MPa}$ で 1 時間の HP により処理する
ことによって $\mathrm{Al}_{2} \mathrm{O}_{3}-\mathrm{HAp}$ 系複合セラミックスの作製を試 みた。 $\mathrm{Al}_{2} \mathrm{O}_{3}$ 䊉子の分散状態や焼結による結晶相の変化及 び焼結体の機械的性質と微構造の関係等を調べた。

本実験で得られた知見を以下に示す。

（1）分散した $\mathrm{Al}_{2} \mathrm{O}_{3}$ 粒子は湿式処理体，水熱処理体で 共にHAp マトリックス中にほぼ均一に分散していたが， ミスト熱分解により得られた球状 $\mathrm{Al}_{2} \mathrm{O}_{3}-\mathrm{HAp}$ 系（M$\mathrm{Al}_{2} \mathrm{O}_{3}-\mathrm{HAp}$ 系) 複合燒結体中には $\mathrm{Al}_{2} \mathrm{O}_{3}$ 粒子の結晶化の 段階で形成された $\mathrm{Al}_{2} \mathrm{O}_{3}$ 粒子同士の凝集体が部分的に生 じていた。

(2) $\mathrm{Al}_{2} \mathrm{O}_{3}$ 粒子の分散は焼結体の密度を低下させ，こ のことは $M-\mathrm{Al}_{2} \mathrm{O}_{3}-\mathrm{HAp}$ 系複合体において顕著であった。 末た，水熱合成粉体加らの焼結体は湿式法からの試料より む高い密度を示し，マトリックスはHAp 単相でめった が，湿式法からの試料のマトリックスは一部 TCP へ分解 していた.

(3) $\mathrm{Al}_{2} \mathrm{O}_{3}$ - $\mathrm{HAp}$ 系複合セラミックスの硬さは，A$\mathrm{Al}_{2} \mathrm{O}_{3}-\mathrm{HAp}$ 系では $\mathrm{Al}_{2} \mathrm{O}_{3}$ 粒子の添加量の増加とともに増 大し，添加率20 vol\%では湿式試料で $856 \mathrm{kgf} / \mathrm{mm}^{2}$ ，水熱 試料で $890 \mathrm{kgf} / \mathrm{mm}^{2}$ とそれぞれ HAp 単体の1.34倍, 1.30 倍の值を示したが， $M-\mathrm{Al}_{2} \mathrm{O}_{3}-\mathrm{HAp}$ 系では $\mathrm{Al}_{2} \mathrm{O}_{3}$ の添加に よって硬さは減少した。

(4) $\mathrm{Al}_{2} \mathrm{O}_{3}$ - $\mathrm{HAp}$ 系複合セラミックスの破壞勒性は $M$ $\mathrm{Al}_{2} \mathrm{O}_{3}$ 系, $A-\mathrm{Al}_{2} \mathrm{O}_{3}$ 系共に $\mathrm{Al}_{2} \mathrm{O}_{3}$ の添加により向上した. また，同じ条件で岕れば $A-\mathrm{Al}_{2} \mathrm{O}_{3}$ 系よりも $M-\mathrm{Al}_{2} \mathrm{O}_{3}$ 系複 合セラミックスの方が勒性は向上して扔り， $\mathrm{Al}_{2} \mathrm{O}_{3}$ の添加 率が20 vol\%では, HAp 単体に比較して湿式試料で1.65 倍，水熱試料で1.80倍の值を示した。高勒化の機構として 分散した $\mathrm{Al}_{2} \mathrm{O}_{3}$ 粒子によるクラックの湾曲及び偏向によ る強化があげられる。

謝 辞 本研究の一部は(財)泉科学技術財団の助成を受けて 実施したものです。

\section{（1993年日本セラミックス協会年会発表）}

\section{文 献}

1) K. Ioku, M. Yoshimura and S. Sömiya, "Bioceramics", Vol. 1, Ed. by H. Onishi, H. Aoki and K. Sawai, Ishiyaku Euro America, Tokyo and St. Louis (1989) pp. 62-67.

2) A. G. Evans, J. Am. Ceram. Soc., 73, 187-206 (1990),

3）玉利信幸，毛利元哉，近藤 功，案協，95, 806-09 (1987).

4) 井奥洪二, 野間竜男, 石澤伸夫, 吉村昌弘, セラミックス 論文誌，98，1334-42 (1990)

5）井奥洪二, 宗宮重行, 吉村昌弘, セラミックス論文誌, 99, 196-203 (1990).

6）野間竜男, 庄司典幸, 和田智志, 鈴木健之, J. Ceram. Soc. Japan, 100, 1175-78 (1992).

7）庄司典幸, 和田智志, 鈴木健之, 吉村昌弘, 野間竜男, 日 本セラミックス協会年会予稿集 (1992) p. 463.

8）新原哠一，セラミックス, 20, 12-18 (1985).

9）青木秀希，牧島亮男編，“バイオセラミックス”，技報堂出 版 (1984) pp. 6-10.

10）鈴木恵一郎，セラミックス，21, 590-97 (1989).

11）西田俊彦, 安田栄一編著, “セラミックスの力学的特性評 価”，日刊工業新聞社 (1986) pp. 82-84.

12）小松和蔵, 佐多敏之, 守吉祐介, 北沢宏一, 植松敬三共訳, “セラミックス材料科学入閏 基礎編”，内田老鶴团（1987） pp. 433-98.

13）日本セラミックス協会編, “セラミックス先端材料一強度と 微構造一”, オーム社 (1991) pp. 246-53。 